\title{
The Russia-China entente and its future
}

\section{Artyom Lukin ${ }^{1}(1)$}

Published online: 13 June 2020

(C) Springer Nature Limited 2020

\begin{abstract}
The 'strategic partnership' between Moscow and Beijing is already more than two decades old and continues to evolve toward more consolidation, a trend which the coronavirus pandemic will only serve to accelerate. Its current state can be characterized as a quasi-alliance, or entente. The article first examines the Russia-China cooperation in the two most crucial areas-geo-economic and military. Then, it asks the question whether Moscow and Beijing could be on the verge of forming an alliance. The article proceeds to analyze the Russian-Chinese interaction in the areas of Eurasia where both of them have significant stakes and intersecting interests: East Asia, the post-Soviet space (with the focus on Central Asia), and the Arctic. Finally, the author draws up several scenarios envisioning the future of the Sino-Russian relationship.
\end{abstract}

Keywords Russia $\cdot$ China $\cdot$ Strategic partnership $\cdot$ Entente $\cdot$ Alliance

\section{Introduction}

The contemporary quasi-alliance between Moscow and Beijing is already more than two decades old. The Sino-Russian 'strategic partnership' was proclaimed in April 1996 as the mid-1990s marked a watershed both in Russia and China's foreign policies. Moscow felt bitter disappointment and even anger with the West and perceived itself being treated as a defeated adversary that could at best be a junior partner in the US-dominated order. At the same time, Beijing was subjected to the humiliation of the 1995-96 Taiwan Strait crisis, which demonstrated China's impotence vis-àvis the American superpower.

After Vladimir Putin succeeded Yeltsin in 2000, there was a brief interlude when Russia attempted to strengthen relations with the West and, for a while, partnership with China lowered in importance for the Kremlin. Yet from the mid-2000s Russia's

Artyom Lukin

artlukin@mail.ru

1 School of Regional and International Studies, Far Eastern Federal University, 125-43/2 Narodny Prospect, Vladivostok, Russia 690014 
relations with the USA and its Western allies began to deteriorate, culminating in the Ukraine crisis of 2014 and the 2016 presidential election meddling scandal. Faced with isolation from the West, Russia pushed for closer ties with China. Beijing was generally receptive. It refused to join the Washington-led campaign of ostracizing Moscow and displayed benevolent neutrality regarding Russian moves in Crimea and eastern Ukraine, but Beijing was cautious in advancing its strategic bonds with Moscow. Although China had its problems with the USA, they were still deemed manageable and Beijing had no intention to antagonize Washington by associating itself too closely with a combative Russia.

By 2018, Beijing calculations might have begun to change, as the consensus gelled in Washington that China presents the most significant national security threat to America. Russia is still considered a major and dangerous rogue state, but Beijing can no longer hope that the Kremlin's shenanigans will distract Washington from dealing with China. The metaphorical Eye of Sauron is now firmly on China, even more so in the wake of COVID-2019. Beijing will either have to capitulate to the USA, renouncing its superpower ambitions, or take a stand. If it chooses the latter, as seems most likely, it needs strong allies to withstand American pressure. Russia is the only available option. This is leading to the present situation when both Moscow and Beijing can see it worthwhile to significantly upgrade their strategic partnership, possibly elevating their relationship to the level of a de facto or perhaps even de jure alliance.

Recognizing that the Moscow-Beijing entente is a complex and multidimensional phenomenon that cannot be entirely described and understood by using just one or two IR theories, the author still believes that Waltzian structural realism and the English School are the theoretical approaches that best capture the contemporary strategic partnership of Russia and China. Structural realism is first and foremost about the balance of power and polarity in international politics, the overriding concern for Moscow and Beijing. At the same time, Russia's modern foreign policy discourse, and its strategy with regard to China, has a lot of affinity with Hedley Bull's version of the English School. Apart from its emphasis on maintaining the balance of power as opposed to unipolar hegemony, the classical English School is in favor of the great-power, concert-like management of international relations (Lukin 2018). This is exactly the model Russia seeks to pursue with the USA (so far, unsuccessfully) and with China (thus far, quite successfully).

The article first examines the Sino-Russian cooperation in the two most crucial areas-geo-economic and military. Then, it asks the question whether Moscow and Beijing could be on the verge of forming an alliance. The article proceeds to analyze the Sino-Russian interaction in the areas of Eurasia where both of them have significant stakes and intersecting interests: East Asia, Central Asia and the Arctic. Finally, the author draws up several scenarios envisioning the future of the Sino-Russian relationship. 


\section{Moving into China's economic orbit}

Since 2009, China has ranked as Russia's top trading partner as an individual country. In 2018, for the first time, Russia-China trade exceeded $\$ 100$ billion, reaching \$107 billion, accounting for 15 percent of Russian exports and imports (RT 2019). Since the Ukraine crisis in 2014, Russia saw the exports and imports with all of its top ten trade partners decrease-except China. From 2014 to 2019, Russia-China trade volume rose by $17 \%$ (Visloguguzov 2019).

On the one hand, Russia's pull into China's geo-economic orbit is inevitable, driven by the logic of the international marketplace. China needs huge volumes of natural resources and Russia is a major supplier of these. On the other hand, Russia's embrace of China as the main economic partner was a political decision born of the Ukraine crisis and the ensuing confrontation with the West. In order to withstand Western pressure Russia needed a strong external partner. As Alexander Gabuev (2016:3) puts it,

[i]t was hoped that China would become a major buyer of Siberian hydrocarbons, Shanghai and Hong Kong would become the new London and New York for Russian companies seeking capital, and Chinese investors would flock to buy Russian assets, providing badly needed cash, upgrading the country's aging infrastructure, and sharing technology.

Not surprisingly, it was in the area of hydrocarbons that Russia's economic pivot to China has been the most impressive. Since 2015, Russia has increased the oil exports to China by $60 \%$ (Kiselyov 2019), displacing Saudi Arabia as China's top supplier of crude oil. In December 2019, the Power of Siberia pipeline started delivering natural gas to China. Chinese state-owned companies are stakeholders and major buyers of liquefied natural gas from Russia's projects in the Arctic. Russia has also been increasing food supplies to China (Grove and Kurmanaev 2019).

Two recently completed bridges across the Amur River-one for rail traffic and the other for vehicles-symbolize Russia's growing closeness to China. It is remarkable that for centuries the Amur has been the main boundary between Russia and China, but there was not a single permanent bridge across the border river. China's economic decoupling from the USA (Wang 2019) is likely to increase Beijing's long-term interest in Russian commodities. Russian supplies, most of which come overland, are also more secure in the light of a possible trade embargo and naval blockade-options the USA and its allies may take in a military conflict with China.

Russia's turn to China-and away from the USA - is happening in the financial domain too. In 2018 Russia's Central Bank drastically reduced the share of its assets held in the USA from 29.9 to $9.7 \%$. At the same time, the Central Bank increased its Chinese holdings from 2.6 to $14.1 \%$. The share of the Russian Central Bank's dollar-denominated reserves also decreased from 45.8 to $22.7 \%$, while its yuan holdings jumped from 2.8 to 14.2\% (Bank of Russia 2019). In June 2019, Moscow and Beijing inked an agreement to switch to national currencies in bilateral trade as they ramp up efforts to move away from the US dollar (Ministry of Economic Development of the Russian Federation 2019). 
However, the reality of closer economic relations with China turned out to be more complicated than initially expected. The most disappointing for Moscow is the failure to attract Chinese FDI. As Kremlin officials admit, 'it cannot be said that China invests a lot in the Russian economy' (TASS 2019a). So far Chinese investors largely demonstrate a wait-and-see approach to Russia. Similar to other foreign companies, they tend to see the risks of entering Russia as high, whereas the profit margins are not substantial enough to offset the risks. To Chinese business, Russia is of interest mainly as a supplier of natural resources such as minerals, hydrocarbons or timber. However, most of these resources are not unique and can be imported from elsewhere, as long as maritime routes remain open. Marine freight is inexpensive, canceling out Russia's seeming advantage of proximity to the Chinese market. At the same time, the freezing winter temperatures, difficult terrain and lack of transport and energy infrastructure across much of Russia often result in higher costs to extract and deliver its natural riches, compared to competitors in Africa, South America or Southeast Asia. Somewhat ironically, even though, post-2014, Russia turned to China to avoid Western sanctions, some Chinese banks, including state-owned ones, have restricted transactions with Russian clients for fear of US penalties. This reflects the reality of US financial sway over China that is unlikely to disappear in the near future (IntelliNews 2018).

As Moscow moves into Beijing's economic orbit, it is still determined to avoid the level of dependency that could pose risks to Russia's political independence and sovereignty. The Kremlin keeps limits in place that should prevent Russia from being too closely integrated with the Chinese economy and save Russia a significant degree of economic autonomy. In addition to refusing to sell China strategic assets, such as ports, such limits are manifested in Russia's reluctance to accept Chinese loans. As one observer points out, 'the Russian government is careful not to incur sizeable debt to China' (Kashin 2019a), which is due not only to the Kremlin's general aversion to accumulating foreign debt, but is also guided by the resolution to deny China financial leverage over Russia. Furthermore, Moscow is in no hurry to work toward a free trade agreement with China, limiting itself to a non-tariff trade facilitation agreement that became effective in October 2019. Russian officials have repeatedly stated that Russia and its fellow Eurasian Economic Union members are not yet ready to open their markets to China (Evraziya.Expert 2019).

Technology is currently the weakest link in the Sino-Russian economic cooperation. Technological nationalism on both sides is a major obstacle. Russia and China have yet to show they can effectively collaborate on major hi-tech projects and achieve the levels of technological integration and division of labor found in the West. Previously agreed projects, such as the joint development of a wide-body passenger jet able to compete with Boeing and Airbus, have not made much progress. This, however, can change as Russia and China are losing access to Western technology. As Bendett (2019) pointed out.

[o]ver the past couple of years, US policy has sought to limit Chinese and Russian engagements with the global technological ecosystem, including through sanctions and export controls. Under these geopolitical circumstances, the determination of Chinese and Russian leaders to develop indigenous replace- 
ments for foreign, particularly American technologies, from chips to operating systems, has provided further motivation for cooperation.

Digital will be one key sector indicating the progress of Russian-Chinese hightech cooperation. Moscow has signaled that Russia will be happy to use Chinese 5G and IoT technology, provided the manufacture of hardware is localized in Russia. Huawei is expanding its presence in Russia, planning, among other things, a fourfold increase of its Russian-based R\&D staff (Makarova 2019). That said, it remains to be seen if Chinese hi-tech companies will agree to share with Russia the core parts of their R\&D and production processes.

\section{The Russia-China military axis}

Russian weapons sales contributed a lot to China's military modernization in the 1990s and 2000s. However, for a long time, it was India, rather than China, that was the privileged buyer of Russian arms: Moscow was willing to supply New Delhi with some of Russia's top-notch weapons and related technologies, while generally selling less advanced systems to China. This pattern changed in the mid-2010s, when Moscow agreed to sell China two of its best conventional weapons, S-400 surface-to-air missile systems and Su-35 fighter jets, making Beijing their first foreign buyer (Putz 2015; Novichkov and Hardy 2014).

Russia's assistance to China is no longer limited to conventional weapons. In October 2019, Putin made a sensational revelation that Russia is helping China build a 'missile attack early warning system' (EWS) that allows to detect incoming ICBMs (Stefanovich 2019a). Only the USA and Russia currently possess such systems that are crucial components of their strategic deterrence capability. This signifies a qualitative raise of the Russia-China military-political and technological cooperation.

Russian experts expect more joint efforts by Russia and China in areas such as strategic missile defense, hypersonics and nuclear-powered submarines. They note that Russia's current military collaboration with China is mostly in areas which should not jeopardize Russia's national security but will significantly complicate the US's military planning vis-à-vis China (Kashin 2019b). Moreover, Russia-China cooperation in military technology is no longer a one-way street. Even though China still relies heavily on Russia in areas such as high-performance aircraft engines, Beijing has outpaced Moscow in AI, shipbuilding and drones. As one Russian military expert notes: 'In the not so distant future, China could be the one selling arms to Russia, such as drones or ships...China has a potent shipbuilding industry. They make their frigates and destroyers like hot buns on a stove. It is totally possible to order hulls for our prospective ships from China' (Simes 2019).

Another important area of Sino-Russian military cooperation is joint exercises. Although Russian and Chinese forces have been regularly exercising together since 2005, the watershed moment came in September 2018 when China participated in Russia's Vostok-2018 strategic maneuvers held in the Russian Far East, allegedly the country's largest military exercise since 1981. China sent a relatively sizeable 
contingent of 3200 troops accompanied by military hardware including 30 aircraft. As Michael Kofman (2018) points out, Russia's invitation of China to the Vostok exercise and Beijing's decision to increase the profile of its military-to-military engagement with Moscow send important signals:

First, if China were not taking part, any exercise on this scale would inherently rouse suspicion from Chinese officials that the war games are aimed at them... The goal is to appear friendly, making sure that the capabilities exercised are not perceived as a threat. Indeed, starting in 2014, Moscow has been careful to make the exercise scenario for Vostok based more on aerospace and naval attack-i.e., aimed at US expeditionary forces and their Pacific allies, as opposed to a land-based contingency that implies fighting Chinese forces. Official Chinese involvement is yet another indicator that Russia and China are more inclined to balance the USA rather than each other.

In August 2019, Russia again invited China to take part in its main strategic maneuvers of the year, dubbed Tsentr-2019. Although the exercise's official focus was on 'counterterrorist' operations, the drill included repelling enemy air strikes and counterattacks against a conventionally armed state. In other words, Russia and China were practicing to jointly deal with a nation-state enemy, if only at a minuscule scale (Gady 2019).

In May 2015, in a move fraught with symbolism, Russia and China conducted their first naval exercise in the Mediterranean, NATO's maritime backyard, while in 2016 and 2017 naval maneuvers were also held in sensitive geopolitical areas-in the South China Sea and the Baltic Sea.

In July 2019, Russia and China conducted the first joint air force operation beyond their national borders. Russian and Chinese long-range nuclear-capable bombers accompanied by fighter jets and surveillance aircraft carried out a patrol over the East China Sea and the Sea of Japan. The patrol's route ran over a sensitive area in the vicinity of the Dokdo (Takeshima) islands, disputed between South Korea and Japan. Seoul claimed that a Russian military plane from the joint patrol group twice violated Dokdo's airspace, prompting South Korean interceptor jets to fire hundreds of warning shots (Lendon 2019). China and Russia apparently sought a maximum demonstration effect. Russian defense minister Sergey Shoigu left little doubt that the joint air patrol was a signal to Washington and its Asian allies: 'As two neighbors seeking strategic partnership, Russia and China are thus messaging to everyone that they want to ensure their security' (Loktionova 2019).

China's top military officials have also occasionally made statements indicating that military cooperation with Russia has America as the main addressee. While in Moscow for ' $2+2$ ' talks with Russian defense and foreign ministers, China's Minister of Defense Wei Fenghe said his visit was a signal to 'let the Americans know about the close ties between the armed forces of China and Russia' (Lo 2018). China's public documents are not so explicit. However, they also indicate the elevated status of China-Russia political-military ties. In China's 2019 White Paper on national defense Russia is mentioned 24 times, up from two in the 2015 edition (The State Council Information Office of the People's Republic of China 2019). According to the document, '[t]he military relationship between China and Russia 
continues to develop at a high level, enriching the China-Russia comprehensive strategic partnership of coordination for a new era and playing a significant role in maintaining global strategic stability.'

As Kashin (2018) notes of Russia and China, 'the scale and nature of their joint activities in the military, security, and defense technology fields are consistent with preparation for possible joint military action against a major hostile country.' The Sino-Russian axis is already beginning to seriously complicate the American military posture. As some American commanders acknowledge, the USA does not have the capacity to deal simultaneously with a resurgent Russia in Europe and the Chinese challenge in the Pacific (Associated Press 2018). A scenario in which China and Russia take coordinated military actions in the Pacific and European theatersfor example, China invades Taiwan while Russia launches a large-scale military operation in Europe (Newsham 2019)—no longer looks purely imaginary.

Northeast Asia is currently the most suitable theater to operationalize an emerging military alliance of Moscow and Beijing. Russia and China have a direct presence in the region, where they maintain substantial military potentials that-if combined - can complement each other. And importantly, it is in the North Pacific where they both directly intersect with the USA. Some Russian analysts believe one of the next steps in the military collaboration could be forming a shared pool of support assets, such as AWACS aircraft and tanker aircraft, to assist Russian and Chinese forces operating in the Pacific (Stefanovich 2019b). If the China-Russia military partnership continues its upward trend, it will inevitably affect the security order in the Western Pacific. Joint actions by Russia and China can challenge the system of US-centered alliances in East Asia and alter the strategic balance there. In future, China-Russia patrols and other combined military missions contesting the US military preponderance are also possible beyond East Asia, for example, in the Atlantic, Middle East, or even the Caribbean, especially as China grows its power projection capabilities and builds a network of overseas military bases, such as in Djibouti and Pakistan's Gwadar.

\section{The return of great-power alliances?}

The rising levels of diplomatic, geo-economic and military collaboration between Russia and China inevitably lead to the question whether they could be on the verge of forming an alliance. Officially, both Beijing and Moscow have repeatedly denied any intentions to create a political-military alliance. For example, in October 2019 Russian minister of foreign affairs Sergey Lavrov emphasized that Russian-Chinese relations 'have never been at such a high and trusting level in all spheres,' but asserted at the same time that 'neither Russia nor China are planning to set up a [military] alliance' (TASS 2019b). That said, Lavrov immediately added some ambiguity to his statement, remarking that the two powers are 'allies' when it comes to 'defending international law' and opposing 'intervention in domestic affairs' (TASS 2019b). In the same month, none other than Putin himself called Russia-China ties 'an allied relationship in the full sense of a multifaceted strategic partnership' (Putin 2019a). This is not the first time Putin has characterized Russia and China as 'allies'. 
In October 2014, meeting with Premier Li Keqiang, the Russian leader referred to the two countries as 'natural partners and allies' (Ng 2014). Russian top officials' occasional use of the 'A-word' with respect to China is hardly a slip of tongue or a mere figure of speech. The ambiguity in describing the relationship with China is likely deliberate and strategic, designed to signal to the West that Moscow is just one step away from forming a full alliance with Beijing.

$\mathrm{Xi}$ Jinping and other Chinese officials have never publicly called relations with Russia as 'allied'. This is not surprising as doing so would directly contradict China's non-bloc and non-alignment pledges which are still part of Beijing's official doctrine. Beijing might also be careful not to excessively provoke the USA with pronouncements of an alliance between America's chief great-power competitors. Moreover, some prominent Chinese experts publicly question the wisdom of a SinoRussian alliance, citing previous precedents. Former vice foreign minister Fu Ying reminds that there had been three alliances between Beijing and Moscow (concluded in 1896, 1945 and 1950) and all three failed (Ying 2016). That said, official Beijing has never refuted Moscow's periodic invocation of the alliance language with respect to the Russia-China ties, which can be interpreted as the desire to maintain some ambiguity [1].

The 2001 China-Russia Treaty of Good-Neighborliness and Friendly Cooperation may already provide some legal grounds for a military alliance. Its Article 9 states: 'When a situation arises in which one of the contracting parties deems that peace is being threatened and undermined or its security interests are involved or when it is confronted with the threat of aggression, the contracting parties shall immediately hold contacts and consultations in order to eliminate such threats' (Ministry of Foreign Affairs of the People's Republic of China 2001). This implicitly suggests the possibility of joint planning and joint military actions to confront common threats and adversaries. Such wording is not much different to the rather vague language found in the Western alliance treaties, such as NATO's Article 5 or Article 5 of the 1960 US-Japan Security Treaty (Kashin 2019c). All those treaties leave it up to the parties to decide whether to commit military forces to assist treaty partners in case of an emergency - and in what manner. What matters even more than the legal language is the concrete degree and scope of joint military planning, interoperability and military-technological partnership (Kashin 2019c). Ultimately, there needs to be the political will to execute formal alliance commitments when push comes to shove. As evidenced by statements from some key NATO leaders, such as US president Donald Trump and French president Emmanuel Macron, there is less than full confidence in the willingness of the North Atlantic alliance to defend its members (Economist 2019). In this sense, the Russia-China strategic partnership, albeit not a formal alliance, may already be no less effective than some of the US-led treaty alliances. Russia and China may or may not adopt legally binding mutual defense obligations à la NATO's Article 5. In the near future this seems rather unlikely, albeit not inconceivable in the longer term. What is almost certain, though, is that Beijing and Moscow will continue to expand and deepen their strategic collaboration in various areas tantamount to building a de facto alliance.

One frequently-heard objection to the possibility of a Sino-Russian alliance is that Russia would be a dependent and hence resentful partner. There is no denying the 
growing disparity in economic might between Russia and China. However, economic asymmetry is not equal to political subordination. North Korea, for example, depends on China for 90 percent of its trade but still retains full political autonomy. As long as Russia keeps a great-power mindset and wields nuclear weapons, it will not be junior to China politically. After all, Russia has been Europe's resource periphery for centuries while acting politically as a great power. Why not repeat the same pattern with China? Furthermore, while highlighting Russia's growing economic dependence on China, there is probably some underestimation of the degree to which China itself depends on Russia. As long as there is the real-and rising_risk of China clashing with the US (over the South China Sea, Taiwan or other issues), the strong bond with Russia - the only major power that can provide Beijing with diplomatic support, military technology, and secure access to vital commodities-will be crucial for the PRC. With Moscow as a close partner, Beijing can be confident about the security of its northern borders, turning them into 'a stable strategic rear area' (Friedberg 2012).

For a long time, perhaps since 1945, international politics has not seen alliances made up of equal great powers. We have gotten used to the notion of an alliance that consists of the dominant power and its dependent junior partners. This is another reason why it is difficult for many experts and policymakers to imagine a Sino-Russian alliance. However, the return of great-power politics, which many admit is now happening, may revive the 'old-fashioned' great-power alliances between equals, with Russia and China leading the way.

An elegant way to make sense of the Russia-China current strategic relationship is to view it as a great-power entente, falling short of a formal alliance but having grown much closer than the 'strategic partnership' the two countries established in the 1990s. An entente, as Dmitry Trenin (2015) reminds, is a harmonious association of two major powers based on the commonality of some key interests; the perception of common threats; a measure of foreign and security policy coordination; and a degree of empathy between their leaders. Similarly, Franz-Stefan Gady (2019) likens the contemporary Moscow-Beijing axis that opposes the USA to Entente Cordiale, the 1904 Anglo-French agreement that paved the way for France and Great Britain to become allies against Germany and the Central Powers during the First World War.

The Sino-Russian entente is helped by the fact that both Russia and China, in their actual foreign policies, adhere to the classic great-power logic of spheres of influence, notwithstanding their rhetoric about the primacy of the norm of sovereignty and the need to democratize international relations. There appears to be an understanding between them that Moscow defers to Beijing on East Asian issues while, in return, the Chinese recognize Russia's leading political role in much of the post-Soviet space and the Middle East (Kortunov 2017).

\section{Intersecting interests of Russia and China in Eurasia: so far, so good}

China and Russia are the two largest-and neighboring-powers of continental Eurasia. Can two tigers share the same mountain, especially when one great power is rapidly gaining strength and the other is in relative decline? And there seems to be a 
pattern in the history of international relations that two ambitious major powers that share a land border are less likely to make an alliance, while they are more likely to engage in territorial disputes with one another as well as rivalry over primacy in their common neighborhood. There are at least three major parts of Eurasia-East Asia, the post-Soviet space (mainly Central Asia), and the Arctic-where China's and Russia's geopolitical interests intersect, creating potential for competition and conflict. But, on the other hand, if managed wisely, overlapping interests and stakes can also generate opportunities for collaboration. The following sections examine how Russia and China are managing to keep their differences in key Eurasian zones under control while displaying a significant degree of mutual cooperation.

East Asia This is China's 'home region', but also one where Russia, by virtue of possessing the Far Eastern territories, is a resident power. Moscow, which has traditionally been concerned with keeping sovereignty over its vulnerable Far East, does not at present see China as a major security risk on Russia's eastern borders. All border delimitation issues between Moscow and Beijing were resolved in the 1990s and 2000s, while the 2001 Sino-Russian Treaty explicitly states that the two countries have no territorial claims to each other. Furthermore, Moscow is well aware that Chinese military preparations are directed primarily toward Taiwan, the Western Pacific and the South China Sea, not against the Russian Far East. There is the cliché, persistent among the Western media and commentariat, of a Chinese demographic invasion of the Russian Far East. For example, a Wall Street Journal article claimed recently that 'about 300,000 Chinese, some unregistered, could now be settled in Russia's Far East' (Simmons 2019). In reality, the actual number of the Chinese who live more or less permanently in the Russian Far East is far lower, and there are very few cases of illegal Chinese migration. There is no imminent risk of the Russian Far East falling under Chinese control demographically or otherwise.

Not sensing any major Chinese menace to the Russian Far East, Russia has refused to engage in rivalry with China in East Asia. On the most important issues of contemporary East Asian geopolitics Moscow has tended to support Beijing or displayed friendly neutrality. On the Korean Peninsula, Moscow has largely played second fiddle to Beijing. On the South China Sea disputes, although Russia's official stance is strict neutrality, some Russian moves may be seen as favoring Beijing. For example, following the July 2016 Hague tribunal ruling that rejected China's claims to sovereignty over the South China Sea, Putin expressed solidarity with China, calling the international court's decision 'counterproductive' (Reuters 2016).

Russia shares with China the objective of reducing American influence in East Asia and undermining the US-centric alliances in the region. Russian weapon sales are helping China alter the military balance in the Western Pacific to the detriment of the USA and its allies. Russia's decision to assist China with getting its own missile attack early warning system may have also been partly motivated by the desire to strengthen China vis-à-vis the USA in their rivalry for primacy in East Asia. The Russian ambassador to the US Anatoly Antonov hinted as much by saying that this strategic system will 'cardinally increase stability and security in East Asia' (TASS 2019c).

Russian deference to China on East Asian issues, albeit somewhat hurting Moscow's great-power pride, makes geopolitical sense. The Kremlin treats Pacific 
affairs as an area of lower concern than Europe, the Middle East, or Central Asia. Mongolia, which constitutes Siberia's underbelly, is the only East Asian nation that can count on Russian security protection in case it finds itself in danger of external aggression, at any rate a purely theoretical possibility so far.

It would be incorrect to say that Russia has completely withdrawn from East Asian geopolitics. In some cases, Russia does act against Chinese wishes in the Asia-Pacific. One recent example is Russia's quiet determination to keep drilling in the areas of the South China Sea on the Vietnamese continental shelf over which China lays sovereignty claims. The Russian state-owned energy company Rosneft operates on Vietnam's shelf, despite Beijing's displeasure and periodic harassment by Chinese ships (Zhou 2019). Apart from the desire to make profits from the South China Sea's hydrocarbons, Russia may be seeking to support its old-time friend Vietnam-to whom it also sells weapons-as well as demonstrate that it is still an independent actor in East Asia. Through such behavior on China's Southeast Asian periphery, the Kremlin could also be sending the signal to Beijing that, if China gets too closely involved in Russia's backyard, such as Central Asia or the Caucasus, Russia can do similar things in China's. Albeit a friction point between Beijing and Moscow, the activities by Russian energy firms in the South China Sea are unlikely to destabilize the Sino-Russian entente, since Moscow and Beijing need each other on much bigger issues.

The post-Soviet space Russia has vital stakes in the geopolitical space formerly occupied by the Soviet Union and is willing to go to great lengths to defend those interests. It was, after all, a perceived brazen attempt by Brussels and Washington to draw Ukraine into the EU's and NATO's orbit that induced Moscow to take drastic action in Crimea and eastern Ukraine, causing a rupture with the West.

When it comes to Moscow-Beijing politics over the post-Soviet space, the most problematic question is certainly about Central Asia, a region composed of five former Soviet republics which shares borders with both Russia and China. Since the nineteenth century, Russia has traditionally considered Central Asia as its sphere of influence. However, in the 2000s China began its economic expansion in the region. It is now by far the biggest trade partner for Central Asian states (Bhutia 2019) as well as its largest source of investments. China also set up a small military presence inside Tajikistan, apparently to secure a sensitive area which borders China's Xinjiang region and Afghanistan (Lo 2019).

Despite initial misgivings in Moscow, China's economic penetration of Central Asia has not, so far, done any substantial harm to Russian interests. Just like Russia itself, Central Asian 'stans' are moving extremely cautiously with respect to Beijing's calls for a free trade area, fearing their economies will be devoured by China. Moreover, populations in Central Asia, particularly in Kazakhstan and Kyrgyzstan, exhibit high levels of Sinophobia. Russia is rather confident the Central Asians are not going to abandon it in favor of China. On the contrary, they may need Moscow even more to hedge against Beijing's rising geo-economic influence.

Multiple predictions by Western analysts that Moscow and Beijing would inevitably clash over Central Asia have thus far been proven wrong. In a stark contrast to the Russian-Western antagonism over Ukraine, Russia and China were able to establish an understanding - and strike a rather stable balance-in Central Asia, 
whereby Beijing has emerged as the main economic force while Moscow retains the status as Central Asia's chief political-military ally and partner. There will be some irritants, but a clash of Chinese and Russian interests in Central Asia is unlikely in the foreseeable future (Zogg 2019).

Central Asia is the most important but not the only area in the post-Soviet space where Chinese rising involvement could potentially come at the expense of Russia. In recent years, China has shown an increasing interest in the South Caucasus, a strategic region comprised of the three former Soviet republics of Georgia, Armenia and Azerbaijan. The South Caucasus' geographic location makes it an important part of China's Belt and Road Initiative. As an observer notes, '[f]or all three countries, China plays the role of an alternative to Russia and the West. Tbilisi, Yerevan, and Baku are all tired of Moscow, Washington, and Brussels eternally squabbling on their own territory. In this respect, Beijing is seen as a possible counterbalance' (Markedonov 2019). There is also an issue of Beijing's flirtation with Belarus, Russia's wayward ally. In the fall of 2019, Belarus reportedly expected a 3.5-billionyuan loan from China as an alternative to funding from Russia (EurAsia Daily 2019). Moscow had earlier withheld financial assistance to force Minsk to agree to closer integration with Russia. If China actually helps the Belarusian autocratic leader Alexander Lukashenko get off Russia's financial hook, it will not be to the Kremlin's liking.

It is unlikely Beijing would push the envelope in Russia's 'near abroad'. China's stakes there are, in most cases, not high enough to be worth testing the strategic partnership with Russia. And where China does have important interests in the postSoviet space, such as in Central Asia, the record so far shows that Beijing is able to find mutual accommodation with Moscow.

The Arctic Apart from East Asia and Central Asia, the Arctic is another area where Russia and China's interests may, theoretically, come into conflict. Russia lays claims to a significant part of the Arctic Ocean and views it as a sanctuary vital for the country's security and economic interests, as well as for the national identity. China, on the other hand, has been displaying Arctic ambitions, calling itself a 'Near-Arctic state' and seeking to gain access to the Arctic's resources, including through the vision for the Polar Silk Road that would see Chinese ships traversing Arctic routes (Xinhua 2018).

Until recently, Russia was wary of letting China into the Arctic. But this seems to be changing. The strengthened Russia-China strategic partnership necessitates a more accommodating attitude by Moscow toward Beijing's Arctic aspirations. Furthermore, with a severely reduced access to Western capital and technology, collaboration with China looks like the only realistic option for carrying out major projects in the Russian Arctic that Russia cannot afford to implement on its own due to their huge costs and technological complexity.

In recent years, Russian officials have repeatedly stated that Russia is ready for more collaboration with China in the Arctic, with the two countries signing a number of agreements on Arctic projects. So far the most important case of the Russia-China Arctic collaboration has been Chinese participation as the biggest foreign stakeholder in the liquefied natural gas (LNG) projects on Russia's Arctic shore (Humpert 2019). Russia also hopes to attract Chinese investment into the Northern 
Sea Route, the Arctic's main shipping artery and a potential maritime corridor between Asia and Europe (TASS 2019d). The Kremlin is apparently betting it will be able to manage China's rising presence in the extreme North without risking Russian dominance of the Arctic.

Russia's embrace of China in the Arctic contrasts sharply with the American stance, with US officials warning that China's intentions cannot be trusted, since its 'pattern of aggressive behavior elsewhere will inform how it treats the Arctic' (Digges 2019).

\section{Conclusion: future scenarios}

Sino-Russian relations are now at their highest point since the mid-1950s, when Moscow and Beijing were communist allies. The Russia-China entente is likely to get even stronger in the wake of the coronavirus pandemic. Facing an intensifying hostility from Washington, Beijing will need Russia-its only major-power friendeven more. Meanwhile, Moscow looks to China, and its continued demand for Russian energy and commodities, as Russia's best chance to recover economically after the pandemic (Gabuev 2020).

Russia and China are being drawn to each other by the most elementary law of international politics: that of the balance of power. From the balance-of-power perspective, it is only natural that two lesser poles should join forces against the preponderant player in the international system - the US Vladimir Putin has repeatedly stated that the Russian-Chinese cooperation is crucial to the creation of 'a multipolar world' as opposed to 'a unipolar structure, with a single centre that governs the entire international community'(Putin 2019b).

In addition to seeing Washington as the main problem in terms of the structural balance of power, both Moscow and Beijing view the US-led West as the primary threat to their political regimes. Indeed, the similarity of Russia and China's contemporary political systems, both being state-centric autocracies, is another crucial pillar of their strategic entente. As a Chinese researcher emphasizes, Russia and China have grown 'increasingly close in their concepts of political governance' and the two countries 'have a greater stake in mutual support to counter political pressure from the West' (Feng 2014). There is cross-pollination taking place between Moscow and Beijing on domestic political issues. For example, the CCP seems to have taken a page from Putin's playbook by introducing regulations, similar to Russia's legislation crippling non-government organization with foreign sponsors or partners, while Moscow borrows from Beijing's experience in controlling the internet. Russia and China presented a united front against 'US meddling' when mass political protests were taking place in Moscow and Hong Kong (Korostikov 2019).

The personalities of the Russian and Chinese supreme leaders, Vladimir Putin and $\mathrm{Xi}$ Jinping, are another major factor in the contemporary Russian-Chinese alignment. Putin and $\mathrm{Xi}$, who are almost of the same age, are getting along very well, and there seems to be a personal affinity between the two. In terms of their political philosophies, $\mathrm{Xi}$ and Putin are on the same wavelength sharing the flair for realpolitik in international affairs, coupled with a conservative and nationalistic 
authoritarianism in domestic politics. Both leaders attach high priority to military force and the security apparatus as tools for defending national interests abroad and maintaining what they see as legitimate order at home. Putin and Xi may stay in power for a long time. Putin's current presidential mandate expires in 2024, but the latest amendments to the Russian constitution allow him to stay on until 2036. Similarly, Xi could remain at the helm even after his current term ends in 2022.

As long as the above factors - the shared perception of the USA as the main external threat, the solidarity of autocratic illiberal regimes, and the leaders' personal affinity-continue to operate between Russia and China, we may expect that the Moscow-Beijing axis will continue to exist, and possibly grow even stronger. It can be assumed, with some degree of confidence, that these conditions will continue in the foreseeable future, at least for the next few years. But, over the longer term, what happens to the Russia-China relationship should the forces currently binding them together weaken or disappear altogether? Several ideal-type scenarios can be drawn up to try to imagine the future of the Russia-China strategic relations over the horizon of seven to 10 years.

Scenario 1. The continuation of the Sino-Russian entente It is quite likely that, even seven or 10 years into the future, the forces that currently sustain the Moscow-Beijing axis will remain in place or could even intensify. Russia and China's rivalry with the USA could grow more acute, while their illiberal autocracies would become even more entrenched. This will result in the continuation of the SinoRussian entente, with ever tighter political, ideological, military and economic ties between Moscow and Beijing, and could even see the elevation of their 'strategic partnership' to the level of a full alliance based on a formal treaty.

Scenario 2. Russia-US rapprochement Even though Russian-American relations are presently at a very low point and unlikely to substantially recover any time soon, in the long term their normalization is not impossible. In fact, the USA will be under increasing structural pressure to make peace with Russia as China looms as by far the biggest threat to America's positions in the international system. At some point, Washington might be forced to seek Moscow's collaboration in managing the massive challenge from Beijing. Although Russia is unlikely to participate in any overt containment of China, it might, at least, agree to become a neutral player. However, Washington will have to make some significant concessions to Moscow, such as recognizing Russia's special interests in Eastern Europe and lifting sanctions. The hypothetical normalization of US-Russia relations would likely have a dual effect on Russia's policy toward China. First, Russia would relax its systemic balancing of the USA and thus have much less incentive to strategically collaborate with China, especially in the political-military domain. Second, if Russia feels secure on its western borders, it will have more freedom to play its own game in East Asia, rather than siding with Beijing, which would, to a degree, help balance China's ambitions.

Scenario 3. Russia and China's political regimes part ways It cannot be ruled out that post-Putin, Russia will transition from illiberal autocracy to a more liberal and democratic regime, more compatible with Western values. If it ever happens, it would weaken Russia's political bonds with the CCP-dominated China, even though the extent of a negative impact is impossible to predict. Some historical analogy could be gleaned from the collapse of the Soviet Union in the early 1990s when 
the post-communist and newly democratic Russia under Boris Yeltsin, which then sought to be part of the West, had to decide about how to proceed with the postTiananmen communist China. Moscow decided in favor of good-neighborly relations with Beijing, albeit at that time it was not a strategic partnership or entente. It is likely that, all other things being equal, Russia and China would be able to keep generally friendly relations even if they have political regimes as different as a liberal democracy in Moscow and a party-state autocracy in Beijing. However, it is an open question whether they would be able to maintain their entente under such circumstances, especially if Russia's political liberalization results in a substantial improvement of its relations with the West. There is the theoretical possibility of a reverse scenario, whereby Russia stays authoritarian while China undergoes democratization and political liberalization. However, such a scenario is less likely as the PRC's party-state appears more viable than Russia's current political regime.

Scenario 4. China's hubris The viability of the Russia-China entente is, to a significant degree, based on mutual recognition of each other as equals. Moscow and Beijing treat each other as co-equal great powers. But the trends that determine the balance of material power between China and Russia could make the maintenance of the political equality a problematic proposition. What happens if China continues to widen the economic gap with Russia - China's economy is already eight times that of Russia'sand increase its lead in many crucial technological areas? The economic and technological asymmetry will also have implications for the military balance between the two: today Russia is still generally considered a more formidable military power than China, but this could change in a decade or so. The situation can be exacerbated by the inevitable change in the top leadership. Vladimir Putin and Xi Jinping seem to have mutual respect for each other, but this might not be the case with their successors. Think of the negative role that the toxic personal relationship between Nikita Khrushchev and Mao Zedong played in triggering the Sino-Soviet split in the late 1950s and 1960s. The post-Xi generation of the Chinese elite could well develop a superiority complex toward Russia and refuse to treat it as an equal partner. Russia might accept the new role of a lesser ally or it might not. If Moscow, out of its great-power pride, insists on full political equality with China, that could rupture the Russia-China axis. Among the four presented scenarios, this one is probably the most dangerous because it involves the matters of status, rank and honor, always the core identity issues for Russia and hence highly emotional (Tsygankov 2012).

The Sino-Russian entente may or may not survive long into the future. What can be predicted with more certainty, however, is that Russia and China will be highly reluctant to be drawn into a hostile relationship. Moscow and Beijing understand that the price of confrontation can be extremely high for both of them. History matters - and the past experience of mutual confrontation is still well remembered in both capitals. As the PRC's consul general, speaking at Far Eastern Federal University in November 2019, put it: 'The lessons from history tell us that the countries must keep friendly relations, taking into account that Russia and China are each other's largest neighbors and considering that the power of each country can do fatal harm to both sides'.

It is likely that the Russia-China relationship will continue to be guided by rationalism and pragmatism, but, of course, there is no guarantee it will stay that way forever. 


\section{Notes}

1. Lower-level Chinese officials can be even more ambiguous in public about the possibility of an alliance with Russia. For instance, when, in November 2019, the PRC's consul general in Vladivostok gave a lecture on Sino-Russian relations at the Far Eastern Federal University, he was asked whether Russia and China would make a military alliance. The diplomat replied that there are no plans for an alliance, but added that 'one can't foresee the future'.

Acknowledgement This research was funded by the Russian Foundation for Basic Research (RFBR) and the Chinese Academy of Social Sciences (CASS), project number 20-511-93005.

\section{Compliance with ethical standards}

Conflict of interest The authors declare that they have no conflict of interest.

\section{References}

Associated Press. 2018. Retired US general says war with China likely in 15 years. NBC News, 25 October. https://www.nbcnews.com/news/us-news/retired-u-s-general-says-war-china-likely-15-years -n924031.

Bank of Russia. 2019. Annual Report 2018. Moscow. http://www.cbr.ru/Collection/Collection/File/19699 /ar_2018.pdf.

Bendett, S. and E. Kania. 2019. A new Sino-Russian high-tech partnership. 29 October. https://www. aspi.org.au/report/new-sino-russian-high-tech-partnership.

Bhutia, S. 2019. The EU's new Central Asia strategy: What does it mean for trade? Eurasianet, 5 June. https://eurasianet.org/the-eus-new-central-asia-strategy-what-does-it-mean-for-trade.

Digges, C. 2019. Russian-Chinese relations are warming the Arctic. Bellona, 24 May. https://bellona.org/ news/arctic/2019-05-russian-chinese-relations-are-warming-the-arctic.

Economist. 2019. Emmanuel macron warns Europe: NATO is becoming brain-dead. 7 November. https:// www.economist.com/europe/2019/11/07/emmanuel-macron-warns-europe-nato-is-becoming-brain -dead?fsrc=scn/tw/te/bl/ed/emmanuelmacronwarnseuropenatoisbraindeadthefutureoftheeu.

EurAsia Daily. 2019. Belorussiya voz'met kredit u Kitaya vmesto Rossii. 25 October. https://eadaily.com/ ru/news/2019/10/25/belorussiya-vozmyot-kredit-u-kitaya-vmesto-rossii.

Evraziya.Expert. 2019. Biznes stran EAES ne gotov k sozdaniyu zony svobodnoi torgovli s Kitayemministr EEK. 10 April. https://eurasia.expert/biznes-stran-eaes-ne-gotov-k-sozdaniyu-zony-svobo dnoy-torgovli-s-kitaem/.

Friedberg, A. 2012. A Contest for Supremacy: China, America, and the Struggle for Mastery in Asia. New York: W.W. Norton.

Yujun, F. 2014. Razdumya ob ukreplenii kitaysko-rossiyskih otnosheniy vsestoronnego strategicheskogo vzaimodeiystviya i partnerstva na fone bolshoi turbulentnosti v mezhdunarodnyh otnosheniyah. In Rossiysko-Kitayskiye Otnosheniya: sostoyaniye i perspectivy razvitiya, ed. K. Kokorev and B. Volkhonsky, 51-53. Moscow: Russian Institute of Strategic Studies.

Ying, F. 2016. Sino-Russian relations: an alliance or partnership? Contemporary International Relations 4: $1-11$.

Gabuev, A. 2016. Friends with Benefits? Russian-Chinese Relations after the Ukraine Crisis. Carnegie Moscow Center, 29 June. https://carnegie.ru/2016/06/29/friends-with-benefits-russian-chinese-relat ions-after-ukraine-crisis-pub-63953.

Gabuev, A. 2020. The pandemic could tighten China's grip on Eurasia. Carnegie Moscow Center, 24 April. https://carnegie.ru/2020/04/24/pandemic-could-tighten-china-s-grip-on-eurasia-pub-81635.

Gady, F.S. 2019. China-Russia: the Entente Cordiale of the 21st century? 7 October, EastWest Institute. https ://www.eastwest.ngo/idea/china-russia-entente-cordiale-21st-century. 
Grove, T. and A. Kurmanaev. 2019. A surprise winner from the US-China trade spat: Russian soybean farmers. The Wall Street Journal, 21 February. https://www.wsj.com/articles/russia-exploits-u-s-china-trade -tensions-to-sell-more-soybeans-11550745001.

Humpert, M. 2019. China Acquires 20 Percent Stake in Novatek's Latest Arctic LNG Project. High North News, 29 April, https://www.highnorthnews.com/en/china-acquires-20-percent-stake-novateks-lates t-arctic-lng-project.

IntelliNews. 2018. Chinese banks comply with US sanctions against Russia. 18 September. https://www.intel linews.com/chinese-banks-comply-with-us-sanctions-against-russia-148751/.

Kashin, V. 2019a. Zapad i rossiysko-kitayskiye otnosheniya: stadii otritsaniya. Valdai Club, 23 May. http:// ru.valdaiclub.com/a/highlights/zapad-i-rossiysko-kitayskie-otnosheniya/.

Kashin, V. 2019b. Tacit alliance: Russia and China take military partnership to new level. Carnegie Moscow Center, 22 October. https://carnegie.ru/commentary/80136.

Kashin, V. 2019c. Neobyavlenny soyuz: kak Rossiya I Kitay vyhodyat na novy uroven' voennogo partnerstva. Carnegie Moscow Center, 18 October. https://carnegie.ru/commentary/80096.

Kashin, V. 2018. The current state of Russian-Chinese defense cooperation. CNA, August. https://www.cna. org/CNA_files/PDF/DOP-2018-U-018184-Final.pdf.

Kiselyov, S. 2019. Energeticheskiye mosty Evrazii. Nezavisimaya Gazeta, 24 October. http://www.ng.ru/ economics/2019-10-24/100_193324102019.html.

Kofman, M. 2018. Vostok-2018: Russia and China signal growing military cooperation. Russia Matters, 10 September. https://russiamatters.org/analysis/vostok-2018-russia-and-china-signal-growing-militarycooperation.

Korostikov, M. 2019 Protesty vklyucheny v povestku sverhderzhav. Kommersant, 10 August. https://www. kommersant.ru/doc/4058816.

Kortunov, A. 2017. Pyongyang starts and wins. What can the losers do? Russian International Affairs Council, 13 November. https://russiancouncil.ru/en/analytics-and-comments/analytics/pyongyang-is-start s-and-wins-what-can-the-losers-do-/Lendon.

Lendon, B. 2019. Why Russia and China are wading into a centuries' old dispute over a tiny island cluster. CNN, 27 July. https://edition.cnn.com/2019/07/26/asia/south-korea-russia-japan-china-warplanes-analy sis-intl-hnk/index.html.

Lo, K. 2019. China increases its presence in Russia's former Central Asian backyard. South China Morning Post, 25 August, https://www.scmp.com/news/china/diplomacy/article/3024261/china-steps-its-prese nce-russias-former-central-asian-backyard.

Lo, K. 2018. US take note: Chinese, Russian militaries are closer than you think, China's defence minister says. South China Morning Post, 4 April. https://www.scmp.com/news/china/diplomacy-defence/artic le/2140301/us-take-note-chinese-russian-militaries-are-closer-you.

Loktionova, M. 2019. "Ne sobiralis' zadirat' SShA": Shoygu obyasnil polyoty Tu-160. Gazeta.Ru, 18 August. https://www.gazeta.ru/army/2019/08/18/12586165.shtml.

Lukin, A. 2018. Russia and the United States in the Asia Pacific: a perspective of the English School. Asian Perspective 42 (3): 307-331.

Makarova, E. 2019. Huawei stalo tesno v Krylatskom. Kommersant, 19 August. https://www.kommersant.ru/ doc/4065780.

Markedonov, S. 2019. Belt and road and beyond: China makes inroads into South Caucasus. Carnegie Moscow Center, 5 November. https://carnegie.ru/commentary/80268.

Ministry of Economic Development of the Russian Federation. 2019. Russia \& China agree to significantly boost trade in ruble and yuan at the expense of the US dollar. 28 June. http://www.ved.gov.ru/eng/gener al/news/19/25081.html.

Ministry of Foreign Affairs of the People's Republic of China. 2001. Treaty of good-neighborliness and friendly cooperation between the People's Republic of China and the Russian Federation. 24 July. https ://www.fmprc.gov.cn/mfa_eng/wjdt_665385/2649_665393/t15771.shtml.

Newsham, G. 2019. War in The Taiwan Strait is not unthinkable: some will lose more than others. Journal of Political Risk, Vol. 7, No. 11, November. http://www.jpolrisk.com/war-in-the-taiwan-strait-is-not-unthi nkable-some-will-lose-more-than-others/\#_ftnref11.

$\mathrm{Ng}$, T. 2014. China and Russia pledge to boost ties and cooperation. South China Morning Post, 15 October. https://www.scmp.com/news/china/article/1616524/china-and-russia-pledge-boost-ties-and-cooperatio $n$.

Novichkov, N. and J. Hardy. 2014. Russia ready to supply 'standard' Su-35 s to China, says official. HIS Jane's 360, 25 November. http://www.janes.com/article/46273/russia-ready-to-supply-standard-su-35sto-china-says-official. 
Putin, V. 2019a. Excerpts from the transcript of the Valdai International Discussion Club session. President of Russia, 3 October. http://en.kremlin.ru/events/president/news/61719.

Putin, V. 2019b. Vladimir Putin's annual news conference. President of Russia, 19 December, http://en.kreml in.ru/events/president/news/62366.

Putz, C.2015. Sold: Russian S-400 missile defense systems to China. The Diplomat, 14 April. http://thedi plomat.com/2015/04/sold-russian-s-400-missile-defense-systems-to-china/.

Reuters. 2016. Putin: Outside interference in South China Sea dispute will do only harm. 5 September. https ://www.reuters.com/article/us-g20-russia-china/putin-outside-interference-in-south-china-sea-disputewill-do-only-to-harm-idUSKCN11B1QC.

RT. 2019. Russia's trade with China surges to more than $\$ 107$ billion. 14 January. https://www.rt.com/busin ess/448783-russia-china-trade-turnover/.

Simes, D. 2019. Is Russia worried about China's military rise? The National Interest, 30 July. https://natio nalinterest.org/blog/buzz/russia-worried-about-china\%E2\%80\%99s-military-rise-70201.

Simmons, A. 2019. On Russia's vast frontier, lots of free land and few takers. The Wall Street Journal, 24 October. https://www.wsj.com/articles/on-russias-vast-frontier-lots-of-free-land-and-few-takers-11571 909402.

Stefanovich, D. 2019a Russia to help China develop an early warning system. The Diplomat, 25 October. https://thediplomat.com/2019/10/russia-to-help-china-develop-an-early-warning-system/.

Stefanovich, D. 2019b. Rossiysko-kitayskiy patrul'. Yandex.Zen, 25 July. https://zen.yandex.ru/media/vat4/ rossiiskokitaiskii-patrul-5d38ad4da660d700b30669ac.

TASS. 2019a Peskov: Rossiya rasschityvayet na uvelicheniye ob'yoma kitayskih investitsiy. 3 June. https:// tass.ru/ekonomika/6500890.

TASS. 2019b Russia, China not seeking military alliance-Lavrov. 2 November. https://tass.com/polit ics/1086654.

TASS. 2019c. Posol RF: sistema Kitaya o preduprezhdenii o raketnom napadenii povysit bezopasnost' regiona. 20 October. https://tass.ru/politika/7021121.

TASS. 2019d. Posol Rossii v KNR: RF I Kitay imeyut real'nye perspektivy sotrudnichestva v Arktike. 20 April. https://tass.ru/ekonomika/6353386.

The State Council Information Office of the People's Republic of China. 2019. China's National Defense in the New Era. 24 July. http://english.www.gov.cn/archive/whitepaper/201907/24/content_WS5d3941dd c6d08408f502283d.html.

Trenin, D. 2015. From greater Europe to greater Asia? The Sino-Russian entente. Carnegie Moscow Center. April.

Tsygankov, A. 2012. Russia and the west from Alexander to Putin: Honor in international relations. Cambridge: Cambridge University Press.

Visloguguzov, V. 2019. V plyuse tolko Kitay. Kommersant, 9 August. https://www.kommersant.ru/ doc/4054828.

Wang, O. 2019 Chinese economists warn Beijing to prepare for decoupling from US. South China Morning Post, 7 July. https://www.scmp.com/news/china/article/3017550/chinese-economists-warn-beijingprepare-decoupling-us.

Xinhua. 2018. China’s Arctic Policy. 26 January. https://www.chinadailyasia.com/articles/188/159/234/15169 41033919.html.

Zhou, L. 2019. As coastguard boats circle, Vietnam prepares for bigger challenge in South China Sea. South China Morning Post. 12 October. https://www.scmp.com/news/china/diplomacy/article/3032536/coast guard-boats-circle-vietnam-prepares-bigger-challenge.

Zogg, B. 2019. Cooperation, co-existence or clash? China and Russia's ambitions in Central Asia. The Diplomat, 8 November. https://thediplomat.com/2019/11/cooperation-co-existence-or-clash-china-and-russi as-ambitions-in-central-asia/.

Publisher's Note Springer Nature remains neutral with regard to jurisdictional claims in published maps and institutional affiliations. 